\title{
Public Interest in Private Law Relations of Transition Democracies: A Modern View from the Standpoint of a Systemic Approach
}

\author{
Iryna E. Berestova ${ }^{1, *}$, Olha V. Verenkiotova ${ }^{2}$, Nataliia O. Serbina ${ }^{3}$ and Svitlana V. Seminoh ${ }^{4}$ \\ ${ }^{1}$ Department of the Jurisdiction Forms of Legal Protection of Subjects of Private Law, the Judiciary and Legal \\ Proceedings, Academician F.H. Burchak Scientific and Research Institute of Private Law and \\ Entrepreneurship of the National Academy of Legal Sciences of Ukraine, Kyiv, Ukraine \\ ${ }^{2}$ Department of Civil Law Disciplines, National Academy of Internal Affairs, Kyiv, Ukraine \\ ${ }^{3}$ Institute of Correspondence and Distance Learning, National Academy of Internal Affairs, Kyiv, Ukraine \\ ${ }^{4}$ Department of the International Private and Comparative Law, Academician F.H. Burchak Scientific and \\ Research Institute of Private Law and Entrepreneurship of the National Academy of Legal Sciences of \\ Ukraine, Kyiv, Ukraine
}

\begin{abstract}
The study investigates the legal nature of the category of "public interest" in private law relations from the standpoint of a systematic scientific approach to law in the countries of post-Soviet society in the modern period. The study states the affiliation of public and private law to the means of achieving the purpose of the law: the recognition of a person, their rights and freedoms as the highest social value of the state. The unsuitability of the theory of the branch belonging to public law has been proved using the universal criterion of separation: the use of the category of "public interest" in the development of the subject and method of the branch in private legal relations. It is concluded that the division of law into private and public is inconsistent in terms of their differentiation of the criterion "method of protecting the rights of their participants", which is activated only after the violation of the latter, while subjective law also exists before the violation, during the existence of regulatory legal relations, and it is the subjective law that forms the affiliation to the relevant industry. During the study, signs of public interest as a legal category were formed. In addition, modern features of public interest as a legal category were outlined from the standpoint of a systematic approach: the general nature of public interests; connectedness with large-scale involvement; recognition by the state and the provision of the law; the possibility of their implementation through measures of state power.
\end{abstract}

Keywords: System method, private law, public law, public interest, state interest, dichotomy of law, civil procedure.

\section{INTRODUCTION}

The term "interest" (Latin "intersum" - it makes a difference; it concerns; it matters) is actively used in various fields of scientific cognition. The universality of the category "interests" is confirmed by its application in philosophy, history, management, economics, pedagogy, psychology, management, legal science, and everyday life (Bakaeva 2010). Public interests as a legal category are manifested in various branches of legal science: constitutional, civil, administrative, tax, banking law, as well as in certain procedural areas of law. The authors of this study consider the systematic research of the legal category "public interests" to be objective. Approaches to determining the legal nature of interest can be described as a global intersectoral problem of legal science, as the legislator does not make provision for a definition of the category "interest" in a purely legal field.

In the context of considering the manifestations of public interest in various social sectors, the positions of

*Address correspondence to this author at the Academician F.H. Burchak Scientific and Research Institute of Private Law and Entrepreneurship of the National Academy of Legal Sciences of Ukraine, Kyiv, Ukraine;

Tel: +38(044)5313173; E-mail: berestova6442-9@murdoch.in such scholars seem remarkable. In particular, the Ukrainian researcher I. Venediktova (2014) covers the general scientific approach to the interpretation of the category of interest, concluding that it constitutes a link that connects people's objective laws and actions. Interest is the simplest form of dispositional relations, which are developed based on the subjective judgment of participants in the historical process regarding the fulfilment of objective opportunities, trends in social development, which objectively arose in the process of their activities and usually gained a foothold in the real social world. The scientist defines interest as "an abstraction, which represents dispositional relations in general, proceeding from the general content, a comprehensive reflection of the active, creative influence of people on the world around them, which changes this world, and in the process of which dispositional relations of people develop and function. In the public life of people, interest takes on the most diverse forms. Depending on the nature of the activity, it is defined in different ways and performs various social roles" (Khanipov 1987).

S. Mikhailov (2002), upon developing the subject and method of public law appeals to the public interest, 
justifying it by the fact that the subject of regulation of public law are social relations caused by the interests of society as a whole, i.e., social relations with the state. The researcher defines the method of regulation as imperative, based on the subordination of interests and designed to centralise social relations. At the same time, the category of public interest outlines the limits of the exercise of the competence of public authorities, and legally it is that public authorities have a special legal personality and competence. Thus, according to S. Mikhailov, public interests objectively limit private interests. O. Malko and V. Subochev (2004) adhere to a similar opinion, emphasising the possibility of fulfilling public interests only with a certain interaction with state bodies, state authorities, what is their main difference. At the proper theoretical and methodological level, the legal nature of the public interest was analysed by a foreign researcher Yu. Tikhomirov (1995), according to whom public interests are not only and not so much state interests as common interests of people, their associations, society in general. The scientist considers the public interest as "... the interest of a social community recognised by the state and guaranteed by law, the satisfaction of which serves as a guarantee of its existence and development".

SYSTEM APPROACH AS A LEADING METHOD OF STUDYING THE SPECIFIC FEATURES OF THE MANIFESTATION OF PUBLIC INTEREST IN PRIVATE LAW RELATIONS

System approach in science is often defined as a general scientific interdisciplinary method, general scientific orientation, which lies in the aspiration to construct a holistic picture of the object, as well as a set of methods and tools to explore the properties, structure, and functions of objects, phenomena, or processes as a system with all the complex interelement relationships, the interaction of elements on the system and external relations (Blauberg et al. 1970). In other words, the essence of the system approach is that the studied object (phenomenon, process) is considered not as a set of its constituent components, but as a system, a holistic formation. Accordingly, the system approach focuses on studying any object (process phenomenon) as a whole, considering its integrative properties, structure, and functions (Obrazhiev 2012).

The application of a systematic approach as a scientific method appears useful for the study of complex objects, solving problems with many variables, and especially the study of social phenomena and processes, one of which is the public interest in the dynamics of their manifestations: during their implementation and as a subject of judicial protection. For example, the Ukrainian civilist A. Kubko (2012) argues that in the course of studying the nature, characteristics, functions, and role of public interests in various branches of law, the position of public interests in the system of social interests and relations with them was ignored. The scientist emphasises that the division of interests according to the content and form of manifestation, as well as the statement of the existence of economic, political, spiritual interests, the interests of society, classes, personal interests is generally accepted; instantaneous and global, long-term, basic, fundamental interests, etc. without recognising the existence of public interests (Sheindlin 1959). Different classifications of interests are presented in the scientific literature, but none of them pays integral attention to the public interest group as a corresponding system.

The position of the modern Ukrainian researcher $\mathrm{M}$. Stefanchuk (2016) appears useful for the systematic analysis of public interest. The scientist examines the grounds and conditions of the prosecutor's office's function of representing the interests of a citizen or the state in court and formulated an original comprehensive definition of the concept of public interest, which is described by the comprehensive application. Thus, the public interest must be understood as "a conscious need that is objectively existing, consolidated in the legal provisions, and has a public (general, social, group, etc.) nature and which on the basis, in the manner and according to a procedure established by law, and in the case when such a restriction is permissible and necessary in a democratic society, can restrict the private interest of individuals and finds its fulfilment (implementation) in a motivated legal activity, as a result of which the corresponding legal relations arise, change, terminate, suspend, and resume". The researcher derives the author's legal formula of public interest as a list of those main indicative legal components in which there may be a public interest.

\section{THE DICHOTOMY OF LAW IN POST-SOVIET STATES: A MANIFESTATION OF PUBLIC INTEREST FROM THE STANDPOINT OF A SYSTEMIC APPROACH}

To cover the legal nature of public interests in law, it is necessary to address the conventional approach to the dichotomy of law in the context of its division into 
private and public law (Azimov 1998). M. Sybiliov (1998) substantiates the consolidation of statutory principles of recognition of the division of law into private and public in Article 3 of the Constitution of Ukraine. It is this Article that stipulates the rule that a person, their life and health, honour and dignity, inviolability and security are recognised as the highest social value, and the main duty of the state, which is responsible for its activities to a person, is to affirm and ensure their rights and freedoms. This approach deserves all possible support. It is a person, their life and health, honour and dignity, inviolability, and security as the highest social value of the state that is the integral purpose of the law. Therewith, public and private law are not a purpose, but different means of achieving it. The main task of private and public law is to create conditions for the fullest self-fulfilment of the interests of society, individuals, and their satisfaction with the state.

The development and implementation of additional goals in practice take place through the functions that constitute the necessary homogeneous, appropriate areas of private and public law, due to the need to meet the objective needs of society, individuals of the state. Public law must ensure the full implementation of private law without distorting it. At the same time, without public law, private law is insufficiently effective or is ineffective at all. The subject and method of public law is often determined by the public interest and the imperative method of legal regulation, based on the subordination of interests, and designed to centralise public relations. However, this theory is unsuitable for certain types of legal relations in which legally equal subjects interact, in particular, participants in civil relations or legal relations arising from the conclusion and implementation of public-law agreements between states (separate parts of states), administrative agreements between public authorities, collective agreements between the employer and employees. In addition, public subjective legal rights and responsibilities can be exercised not only in power relations.

Thus, the method of building legal relations cannot be considered as a universal criterion for the division of law into private and public. The indication that privatelegal relations arise between equal subjects, and public-legal relations - between subordinates to each other, do not always illustrate the specific features of private and public law: in some cases, in public legal relations subordination of one subject to another is also absent. Some scholars consider the method of distinguishing between private and public law as a way to protect the rights of their participants (Muromtsev 2004). According to this concept, the regulation of legal relations in which the initiative to protect the violated subjective right directly belongs to the person concerned is private law, and in the case of initiating protection by an authorised authority, such legal relations are regulated by public law.

The above position is questionable and does not fully meet the criteria for the division of law into private and public, given that the nature of the protection of subjective rights (as understood from the position of $S$. Muromtsev) is activated only after the violation of the latter, although subjective law exists prior to the violation and during the existence of regulatory relations. With regard to the civil and civil procedural spheres, indeed, the method of protection of a subjective right can be manifested only after its violation, but the actual nature of protection, and hence the nature of the subjective civil right, are statutorily defined (or allowed - according to Articles 6, 15 of the Civil Code of Ukraine) prior to the violation, not after it. In other words, it is civil law enforcement, the first stage of which constitutes the selection of a legal provision that will regulate a specific legal relationship and the relevant subjective rights and legal obligations of the participants in such a civil legal relationship. In addition to this, public authorities can file claims to protect the private subjective rights of individuals, especially in terms of civil procedure protection of public interests (Solodovnichenko 2015).

Public interests in private law arouse additional scientific interest as a specific legal tool to ensure the stability of the business. After all, the sphere of private law is described by decentralised regulation on a dispositive basis with the use of its inherent legal means of all personal non-property and property relations based on legal equality, free will, and property independence of subjects (Spasibo-Fateeva 2011). In such a situation, first of all, it is necessary to clarify the general definition of the category "public interest". The first scientific research on the issue of public interest in law contains the works of the famous English philosopher of the Enlightenment J. Lock (Andrushko 2011). The thinker believed that there were many cases that the law could not make provision for, and to resolve them the discretion should be given to those who possess the executive power to dispose of it, as required by the public good while determining life, freedom, health, absence of corporal punishment, right to own money, land as civil interests (Lock, 1960). 
DOCTRINAL DEFINITIONS OF THE CATEGORY "PUBLIC INTEREST"

The American scholar P. Herring considered the result of a compromise of group interests to be in the public interest, which should be "refracted" through the activities of public authorities, which are assigned the role of arbiter of the main interests. Other American scholars A. Bentley and D. Truman, based on their empirical studies of American government, deny the existence of public interest as an objective category, arguing that it is nothing but an abstraction (2002). Modern Ukrainian constitutionalist V. Selivanov (2001) emphasises that the common good if interpreted as legally qualified public interests of society (provided by the state will), should be considered primarily as a general condition for the fulfilment of private interests, aspirations of individuals, as opposed to denying them in favour of public interests, moreover, state interests, in addition to substituting them for the public interests of society.

There is another position that all existing interests in society are personal interests, but have varying degrees of commonality depending on their consistency with similar interests of the majority (Kuszhanova 2000). Interest, which reflects the needs of most individuals in the team, constitutes a kind of interest of the individual with a high degree of commonality - the public interest. As a result of the interaction of social actors, there is a process of development and fulfilment of interests, as a result of which the interest can be transformed in accordance with the interests of the majority into the public interest or cease to exist (Dankov 2014). I. Venediktova (2014), analysing the opinions of other scientists of the postSoviet and modern periods, states that a similar position is held by O. Ilyina (2007), O. Kostin (2002), E. Talapina and Yu. Tihomirov (2002). The scientist also concludes that in a general sense, public interests constitute the common, average interests of a particular social community. In addition, they meet two criteria: on the one hand, they are public interests, without which it is impossible to ensure the integrity and stability of the state and society, in particular, the fulfilment of certain private interests; and on the other hand, they constitute the officially recognised interests that have received the support of the state.

The approach of the Russian researcher $\mathrm{O}$. Kryazhkov (1999) to the essence of public interests, which he interprets exclusively as public interests, "recognised by the state and regulated (provided) by law" appears to be quite interesting. Ukrainian researcher I. Andrushko (2011) synthesises his position: "... the state does not have its own interest, since interest is described by the belonging of a person, a group of persons, and society, to social subjects". In the activities of the state and its organs, as O. Kryazhkov (1999) continues, certain interests that become "state" are manifested only by being reflected in it. Consequently, the state interests are the interests of individual social subjects transformed in its activity. If the social principles of the state are generally replaced by a class or other group component, such as the business elite in the face of financial and industrial groups, then the functioning of the state over the interests of society begins to outweigh the interests of a particular social group. Then the support of this social group acquires state support, thus becoming "state".

Unlike O. Kryazhkov, the Ukrainian constitutionalist M. Savchyn (2009) quite fairly emphasises that the main task of public authorities is to take care of the public interest, which is higher than the state interest. O. Vinnyk (2004), exploring the theoretical aspects of legal support for the fulfilment of public and private interests in companies, notes that "public interests can be defined as reflected in the law, harmonised and balanced interests of the state as an organisation of political power, as well as the interests of the entire society (common interests of its members), a significant part of it, including territorial communities, social groups, especially those of them, who by themselves (due to the lack of, for instance, the appropriate means to pay for the services of a lawyer) are unable to protect their interests by legal means and therefore require state support, in the absence of which increases the likelihood of crisis phenomena in society, strikes, and other collective forms of protest and selfdefence". The researcher substantiates the expediency of using the concept of "public interest" in regulations as more universal one than "state interests", and accordingly - the need to expand the powers of the prosecutor by endowing the prosecutor with the right to file claims in defence of all types of public interests, as well as recognising the prosecutor in this case as an independent party to the procedure.

Russian researcher M. Vasilyeva (2003) notes that the public interest covers two levels. Firstly, the state level - in the part that reflects the interests of society in general. Secondly, the social level - the interests of civil society to the extent that corresponds to the level of their awareness and can be provided with legal protection. Continuing the study of the legal nature and 
signs of public interest, it is necessary to cite the position of Ukrainian civilist A. Kubko (2012), who named several factors that hinder the development of sound approaches to the essence of public interest. In particular, this term ("public interest") has not been widely used at the level of regulations, which could define, at least, general guidelines for its basic properties. Among the few exceptions, the scientist mentions the Paris Convention for the Protection of Industrial Property (1883), Article 5 of which mentions the public interest, but does not interpret this category. The concept of public interest is not widespread in national law. Thus, the Constitution of Ukraine deals exclusively with the interests of national security, economic welfare, human rights, public order, territorial integrity, public health (Articles 32, 34, 36, 39), the protection of which is considered as a basis for restricting the rights and freedoms of a person and citizen, as well as the interests of society (Article 41), which determine a kind of limit to the use of property rights. A similar situation is observed at the level of acts of international law. A typical example is the Convention, which contains a reference to public interests, general interests, as well as the interests of public safety (Articles 8, 9, 10, etc.) (Kubko 2012).

The Fundamental Law of Ukraine constitutes the legal framework for the existence of such a phenomenon as the public interest in national legal science. Article 18 of the Constitution of Ukraine states the existence of national interests; Part 2 of Article 32, Part 3 of Article 34, Part 3 of Article 36, and Part 2 of Article 39 of the Fundamental Law of Ukraine refer to the existence of interests of national security, and Parts 1 and 3 of Article 36 and Part 1 of Article 121 refer to the interests of the citizen, etc. Thus, the Fundamental Law of Ukraine states the existence of the concept of interest as a phenomenon that has legal significance, but in fact, establishes the existence of several types of interests, without interpreting the essence and features of this phenomenon as a legal concept or the relationship between all types of interests the text of the Fundamental Law. Reflecting on the concept of interest in civil law and civil legislation, Ukrainian civilist O. Pervomaisky (2014) fairly states that the concept of interest and its various terminological designations and/or of its types have become widespread in science, legislation, etc., which, however, does not eliminate all problems regarding the interpretation and application of the interest(s). An attempt to solve the scientific problem of the fulfilment of public interests in civil law at the level of dissertation thesis was made by $A$.
Kubko (2012), who concluded that "the fulfilment of public interests is an objective necessity in the civil law of Ukraine", which is possible in this branch of law in two types of means: restrictions and state intervention in civil legal relations.

\section{STATE AND PUBLIC INTERESTS AS TYPES OF PUBLIC INTERESTS IN THE FIELD OF PRIVATE LAW}

During the study of public interest, its manifestations, and types, the matter of the place of public interests among other types of interests logically arises, in particular in the meaning of singling them out into a separate group and the correlation with state interests. Given that the subject of this study is the coverage of the interrelation between constitutional proceedings and civil proceedings in the context of protection of public interests, this study will focus on this subject in constitutional law. Ukrainian researcher I. Andrushko (2011), for example, is convinced that the separation of state interests in the science of constitutional law is absolutely justified. Accumulating the positions of constitutionalists, the scientist develops the definition of state interests as "a balanced set of socially perceived objective needs and needs of state power, which are conditioned by their interdependence and cultural and historical features of development" (Kruss 2007) and emphasises the need to distinguish between state and state apparatus, which tends to pass off its departmental interests as public and state. According to the legislation, the state apparatus should not play the role of a carrier, but only a representative (agent) of the public interest (Totev 2002).

As for the public interest, at first glance, it can be assumed that the distinction between state and public interests, united by the concept of "public", is not of fundamental importance for civil law and civil relations, as, for example, for constitutional law. However, the actions of participants in civil proceedings that violate state interests have a negative impact on society and vice versa. The need to study the category of public good in legal science emerged in the 19th century and was conditioned by the influence of the social theory of law and increasing attention to the issue of the social function of law. The consolidation of the categories of "public order" and "good" in the civil legislation of that period necessitated the study of the concept of the common good, through which they were interpreted (Yatsenko 2016). On this matter, I. Pokrovsky (1998) once wrote that for all the diversity of interests, the good could never be public. That which is good for 
some is always evil for others. Understanding the common good as the good of the majority can lead to the sacrifice of the good of the minority. I.S. Peretersky (1924) also considered the concept of "common good" to be meaningless. Among the modern interpretations of the category of the common good, the position of V.S. Nersesyants (2001) is noteworthy, that the common good reflects the common law principles, i.e., "the formal unity of differences, the common that unites differences". The joint, common good does not mean the denial of various interests, but, on the contrary, provides a "common condition for their possibility".

Legal science contains an approach (which the authors of this study share) that the public interest and the state interest constitute separate legal categories, and they should not be equated (Stepanenko 2008). The concept of public interest is broader than the state interest because the bearer of public interest in society, not the state, which appears as a special political and territorial entity (Mikhailov 1999). It is also possible that the state has independent interests (for example, regarding the material support of its functioning) (Vinnyk 2004). Moreover, the main direction of the democratic transformation of Ukrainian society should be the priority of implementing the principle of public interests of society over the possible private interests of the state (Stepanenko 2008). The public interest is often equated with the state interest, which, in the authors' opinion, is wrong. Firstly, not every state takes due account of all existing public interests, because the recent history of Ukraine only in the last five years is replete with examples when the state acted not just inconsistently, but clearly contrary to the interests of society. The convergence of public and state interests can be assumed in a completely democratic state, but even approximate convergence could not lead to their merger. In a sense, they would intersect, but they can never coincide completely because both the state and society always have interests inherent in only each of them separately.

For example, considering the state of Ukraine as an independent subject of, for example, civil, civil procedural, and other private law relations, one should state the existence of its independent, different from the other participant (opposite party) interest in particular relations. The state's interest in this capacity does not always coincide with the interest of any other possible actors. For example, the state may act as the owner of a plant that emits harmful substances into the atmosphere, thereby harming the life and health of the population (public interest), etc. A. Tumanov (2012) argues: "without taking this into account, contrary to logic, we will have to admit that even when the state clearly opposes the real interests of society, it acts in its interests to the same extent". This situation seems especially legally sensitive in Ukraine in the context of the occurrence of the grounds for compensation for moral and material damage caused to the civilian population and participants in the anti-terrorist operation in certain territories of eastern Ukraine in the conditions of an undeclared but actual war with a neighbouring country.

At the same time, the difference of interests does not exclude the fact that the state must yield in the interests of society. The state can have only its functions, the implementation of which has important social significance. This refers to, for example, taxation. In this case, the interest of society is, first of all, not in taxation as such, but in the fact that the generated budget funds are spent on socially useful needs. Thus, if a citizen does not perform the obligation to pay taxes, the public interest as an object of protection cannot be directly addressed - the interest of society is incidental, because tax collection is a direct task of the state. The direct interest of society should be noted when the issue arises regarding the development of those universal benefits, on which budget funds generated by taxes should be spent (Tumanov 2012). Important in defining interest as the public is that it should be recognised as a good, taken into account by law (it is not necessarily protected directly by law, but is taken into account by law in general as good of society, a particular community with a defined or indefinite circle of person).

Some authors recognise the absorption of the interest of an indefinite circle of persons by the public interest, including in terms of recognition of the public/social interest as a subject of judicial protection (Pokrovsky 1998; Abolonin 2001; Neznamov 2009; Uksusova 1997). It is in the context of the subject of judicial protection that we partially agree with the above position, but with certain reservations and clarifications regarding the legal nature of the delimitation of these legal categories. T.V. Stepanenko concludes that it is possible to consider the public interest as an independent object of judicial protection, not mediated by the protection of the rights of a particular person, justifying it by the fact that the direct object of judicial protection in the investigated category of cases is the impersonal public interest that has a conceptual significance for determining the nature and procedural features of litigation on claims for protection of the 
rights and interests of an indefinite number of persons (Pokrovsky 1998). O. Uksusova (1997) raises the issue of the interest of an indefinite number of people and emphasises that such a practice is in demand given the need to protect the object of a special kind - certain common goods (values). In a broad sense, this protection is aimed at ensuring the legal, economic, social, environmental well-being of society.

In general, adhering to the stated positions, it is necessary to clarify that in many cases, when protecting the rights of an indefinite circle of persons, there is indeed protection of public interest. For example, evidence of public interest can be traced in environmental claims. At the same time, situations are not excluded when, upon applying to the court to protect the rights of an indefinite circle of persons, the issue of protecting the public interest does not arise, since the indefiniteness does not imply the obligatory presence of a certain common good. The only common basis that unites such persons can only be that they cannot all be personified and that their homogeneous rights are subject to protection. In particular, it is difficult to determine the common good in all possible cases of violation of the process in the interests of an indefinite number of investors or copyright and related rights holders by a collective management organisation, as only the individual interests of each of them can be protected. The protection of public interest can be referred to when it is possible to identify all members of a social group. For instance, when preserving certain types of cultural or historical value (e.g., preservation of a monument), which is of importance exclusively for residents of a certain small settlement. Therefore, the public interest is primarily associated not with the number of participants or the indefiniteness of the group, but with its special quality social significance.

The full correspondence of public and state interests, given specific empirical examples, even in Western democracies remains an unattainable goal, a certain ideal, because the relationship "state-society" always contains certain contradictions. In addition, both Ukrainian and foreign constitutional practices contain many examples when, under the guise of national and state interests, the implementation of narrow-group interests of a limited circle of persons occurs. In this regard, the opinion of the German professor of state law W. Weber is correct, who emphasises that the consequence of this situation is quasi-constitutional processes leading to the dismantling of an element of statehood, which ultimately leads to the loss of the actual substance of the state's authority, as defined by the Constitution. T. Stepanenko (2008) formulated a conclusion regarding quite frequent identification of public and state interest. In particular, the researcher summarised the opinions, according to which public interests are recognised by the state and regulated (ensured) by law (Tikhomirov 1995), without which it is impossible, on the one hand, to realise private interests, and on the other hand, to ensure the integrity, sustainability, and normal development of organisations, the state, nations, social strata, and ultimately society in general (Vinnyk 2004); as well as "reflected in the law, harmonised, balanced in a certain way interests of the state as an organisation of political power, the interests of the whole society (the common interests of its members), a significant part of it, including territorial communities, social groups, especially those of them that are incapable of protecting their interests unassisted, using legal means (for example, small entrepreneurs, affiliates, small shareholders, consumers, employees, etc.), and therefore need government support, in the absence of which there is a high probability of crisis phenomena in society" (Totev 2002).

The authors of this study share such position: in a broad sense in civil law and civil procedural law, public interests should be understood as those recognised by the state and considered or ensured by law, without which it is impossible, on the one hand, to realise private interests and, on the other hand, to ensure integrity, sustainability, and normal development of organisations, other entities, social groups, strata, the state, and society in general. Public interests in constitutional law should be considered the most important interests in society and the state. This is the highest level of interests in the constitutional law of Ukraine, since not only the realisation of all other, less significant interests depends on their constitutional and legal content and guarantees, but also, in general, the foundations of the social and state system, which together form the constitutional system of Ukraine (Andrushko 2011). Based on the study of statutory and doctrinal consolidation of public interests and detailed coverage of different, sometimes even polar scientific opinions on the public interest in various branches of law, the features of public interest as a legal category will be formulated below as follows.

The first feature is the general civil nature of public interests. This is their purpose: promoting and ensuring the development of society, its economic, spiritual, political progress, influence on the creation of 
appropriate conditions for the business turnover of society and its turnover in general (Vinnyk 2001). Due to the general civil nature, public interests are always described by a certain mass large-scale involvement. They belong, are statutorily consolidated or organically inherent in society in general or large social groups (for example, labour collectives, consumers in environmental legal relations, etc.), that is, it is mandatory to have a significant number of bearers of these interests. A. Kubko (2012) calls such a feature "quantitative aspect" and justifies that the subject of public interest in society as a whole. Public interests cover a wide range of individuals, groups, social formations, etc. From the standpoint of a systematic study of the legal category of "public interest", this feature is key in the context of the distinction between public interests in public and private branches of law. After all, public interests in private law are manifested in a slightly different way than in public spheres. Since such interests are related to large groups of individuals or society (the state) in general, the next feature reflects a certain concern of the state about the limits of legal regulation and ensuring the stability of the rule of law.

This refers to such an important sign of public interests as recognition by the state and security by law (Kryazhkov 1999). As indicated above, scientists have repeatedly noted the specific consolidation of public interests in legislative acts: they acquire concretisation in general terms or in specific legal provisions of the Constitution of Ukraine and acts of current legislation (Tikhomirov 2001). Above, the study has already abstractly illustrated the consolidation of public interests in the Fundamental Law of Ukraine and their concentrated consolidation, for example, in the Civil Code of Ukraine. Thus, a systematic analysis of the statutory consolidation of public interests suggests that only the interests declared by the state as priority ones and enshrined in legal provisions should be considered public. However, one cannot unequivocally agree with the position of A. Kubko (2012) that it is impossible to recognise interests as public, if, although they provide for large-scale involvement and are perceived by society or significant social groups, at the moment they do not enjoy state support, and the need for their implementation is not reflected in the legislative acts of the state.

The situation in the country in recent years has been described by a noticeable surge in a legislative activity which, unfortunately, is not always systemic. A lot of changes associated with a change in the state course, in the process of their practical implementation, affect the already acquired human and civil rights, various segments of the population, and legal entities in terms of their narrowing and (or) cancellation. Moreover, such legislative actions of the legislator are regular and become widespread, in particular in matters of taxation of pensions, the abolition of special types of pensions, interference with the rights of property owners (bank depositors), social insurance of employers' liability, etc. Thus, these are changes that infringe on the legitimate expectations of individuals regarding their right to peaceful ownership of property. The external reason for such changes is not always properly justified by the legislator references to socioeconomic changes in the country, but most often this is the result of unsuccessful government leadership, which entails massive violations of various rights of citizens.

Therefore, the constitutional guarantees of human rights abstractly declared in Section III of the Fundamental Law and enshrined in the form of a general authorisation in acts, for example, of civil legislation, establish all the necessary legislative grounds for their recognition as a public interest, despite the absence of a specific statutory indication or special warning regarding such an interest. The perception by society or significant social groups forms the social interest, which acquires the features of the public interest and cannot be mechanically brought beyond the limits of the latter. At the same time, it is possible to unambiguously describe it as a public interest only taking into account all the actual circumstances of law enforcement situations in the implementation of such interests by the mentioned groups. Thus, the extremely thin, subjective, and fluid line between private and public interests must be considered. It can be noted that recently there has been a certain convergence of private and public interests, which does not always contribute to their merger, since often private and public interests have polar goals. The foregoing allows formulating such a sign of public interests as the possibility of their implementation with the help of measures of a statepower nature, which is acknowledged by modern legal science (Rabinovych 2004).

A. Kubko (2012) notes in this regard that this aspect of the phenomenon of public interests gives grounds to classify as public interests only those of them that, in their essence, can be implemented using state legal mechanisms. Thus, interests that cannot be realised by state-legal means fall outside the scope of public 
interests, even if society, the state, collectives, and social groups appear to be their carriers. The scientist proves that the general civil nature of public interests, their recognition by the state does not exclude their focus on ensuring the implementation of private interests. Taking this into account, public interests by their nature consider the interests of individual subjects, and the implementation of public interests creates conditions for the satisfaction of private, personal, collective interests, ensures their combination with the interests of the state. In this context, attention is drawn to the approaches expressed in the Ukrainian and foreign legal literature, according to which public interests are considered simultaneously as a set of private and national interests (Haivoronskyi 1997); as public interests, without the satisfaction of which it is impossible to ensure sustainable development of the state, society, social strata, or to realise private interests (Tikhomirov 1995); as a public good, which implies a balanced settlement of contradictions between personal needs and the state, between the freedom to exercise property rights and the social obligations of the owner (Frenzel 1978; Alekseev 1999; Braginsky 2000; Kharytonov 2000; Kharytonov and Kharytonova 2000; Kolodii 1997; Prangishvili 2000; Rabinovych 2004; Kipnis 2004); as the sum of all private interests in society, balanced for the common good.

\section{CONCLUSIONS}

This study considered modern opinions on the manifestation of public interest in private law (mostly civil) relations from the standpoint of a systemic approach. It is concluded that a person, his or her life and health, honour and dignity, inviolability, and security as the highest social value of the state is the only purpose of law in general. Public and private law is not a purpose, but different means of achieving the said purpose, their main objective is to create conditions for the fullest self-fulfilment of the interests of society, individuals, and their satisfaction with the state. This study analysed the dichotomy of dividing law into private and public in individual post-Soviet countries, as a result of which, using the universal criterion of "public interest", it was proved that the theory of the branch belonging to public law is unsuitable for the formation of the subject and method of the industry in certain legal relations. These are legal relations where legally equal subjects interact, in particular participants in civil relations or legal relations arising from the conclusion and implementation of public law agreements between states (separate parts of states), administrative agreements between public authorities, collective labour agreements between employer and employees.

From the standpoint of a systematic approach, it is worth noting the priority of public interests in constitutional law as the interests of the highest level, constitutionally enshrined (which form the constitutional system of the country) or those that are inherent in the constitutional and legal meaning and the guarantee of their implementation by branch-related legislative regulation. In legal relations where legally equal persons interact, public interests constitute an objective necessity and arise as a general condition for the realisation of private interests, serving the purpose of ensuring the existence of society as a whole. However, the realisation of public interests in constitutional proceedings and civil proceedings are different, and therefore it is considered appropriate to cover such specific features in the following studies on this subject.

This study substantiated the doubtfulness and inconsistency of the position, according to which the criterion for dividing the right into private and public constitutes the way to protect the rights of their participants. Despite the fact that the nature of the protection of subjective law is activated only after the violation of the latter, the subjective right exists prior to the violation and during the existence of regulatory relations. In particular, with regard to the civil and civil procedural spheres, the nature of the subjective civil right is statutorily defined (or allowed) before the violation, and not after it, although the method of protection of subjective law is manifested only after its violation. This is civil law enforcement, the first stage of which is the selection of a legal provision that will regulate a specific legal relationship and the relevant subjective rights and legal obligations of the participants in such a civil legal relationship.

\section{REFERENCES}

Abolonin, Gleb. 2001. "Problems of accessibility and efficiency of justice on the example of the rights and interests of numerous groups of persons". Arbitration and Civil Procedure 4: 2-9.

Alekseev, Sergei. 1999. Private law. Moscow: Statut.

Andrushko, Iryna. 2011. "The category of "public interest" in constitutional law: concept and content". Magazine of Kyiv University of Law 4 : 137-141.

Azimov, Chynhizkhan. 1998. "Concept and content of private law". Bulletin of the Academy of Legal Sciences of Ukraine 3(14): 1558.

Bakaeva, Olga. 2010. The ratio of private and public interests in the context of reforming the legislation of the Russian Federation. Moscow: Yurlitinforma.

Blauberg, Igor, Vadim Sadovskiy and Erik Yudin. 1970. System approach in modern science. Problems of system research methodology. Moscow: Mysl. 
Braginsky, Mikhail. 2000. About the place of civil law in the system "public law - private law". Moscow: Norma.

Dankov, Anton. 2014. Ensuring the balance of public and private interests in the sphere of justice. Moscow: Russian Academy of Justice.

Frenzel, Max. 1978. The public interest as a prerequisite for expropriation. Berlin: Duncker \& Humblot.

Haivoronskyi, Volodymyr. 1997. "Civil law: from "nothing private" to "nothing public". Bulletin of the Academy of Legal Sciences of Ukraine 4: 91-100.

Ilyina, Olga. 2007. Private and public interests in family law of the Russian Federation. Moscow: RSL.

Khanipov, Anton. 1987. Interests as a form of public relations. Novosibirsk: Nauka.

Kharytonov Yevhen. 2000. History of private law in Europe: Eastern tradition. Odessa: Yurydychna Literatura. 262 p.

Kharytonov, Yevhen and Olena Kharytonova. 2000. "On the concept of the meaning of the dichotomy "private law - public law". Bulletin of the Academy of Legal Sciences of Ukraine 2(21): 83-89.

Kipnis, Nikolai. 2004. In defense of public interests. Moscow: Yurist.

Kolodii, Anatoliy. 1997. Principles of law of Ukraine. Kyiv: Yurinkom Inter.

Kostin, Andrey. 2002. "Interest of public-territorial entities in civil law". Legislation 3: 13-19.

Kruss, Vladimir. 2007. The theory of constitutional legal use. Moscow: Norma.

Kryazhkov, Aleksandr. 1999. "Public interest: concept, types, and protection". State and Law 10: 91-99.

Kubko, Andriy. 2012. Realisation of public interests in civil law of Ukraine. Kyiv: Taras Shevchenko National University of Kyiv.

Kuszhanova, Azhar. 2000. "Problems of classification and interaction of interests". Credo 5. Retrieved October 08, 2020 (http://credonew.ru/content/view/195/25).

Lock, John. 1960. Selected philosophical works. Moscow: Mysl.

Malko, Aleksandr and Vitaliy Subochev. 2004. Legitimate interests as a legal category. St. Petersburg: Juridicheskii Centr Press.

Mikhailov, Sergei. 2002. Category of interest in Russian civil law. Moscow: Statut.

Mikhailov, Stanislav. 1999. "Interest as a general scientific category and its reflection in the science of civil law". State and Law 7: 86-92.

Muromtsev, Serhiy. 2004. Definition and basic division of law. St. Petersburg: Saint Petersburg State University.

Nersesyants, Vladik. 2001. Philosophy of law: textbook. Moscow: Norma.

Neznamov, Aleksandr. 2009. "Some aspects of the development of public interest law in Russia". Arbitration and Civil Procedure 6: 2-4.

Obrazhiev, Konstantin. 2012. "Systematic approach in jurisprudence: theoretical and methodological foundations". Bulletin of the Leningrad State University named after A.S. Pushkin 2(1): 89-96.

Paris Convention for the Protection of Industrial Property. 1883. Retrieved October 10, 2020 (http://zakon.rada.gov.ua/laws/show/995_123)

Pereterskiy, Ivan. 1924. "Compulsory and dispositive norms in the law of obligations of the Civil Code". Soviet Law 4: 68-80.

Pervomaisky, Oleh. 2014. "The concept of interest in civil law and legislation". Legal Ukraine 11: 53-47.

Pokrovsky, losif. 1998. Basic problems of civil law. Moscow: Statut.

Prangishvili, Iveri. 2000. System approach and general system laws. Moscow: Sinteg.
Rabinovych, Petro. 2004. "Natural law: the dialectic of private and public". Law of Ukraine 9: 61-64.

Rabinovych, Petro. 2004. "Private and public in natural law and Ukrainian legislation". Legal Ukraine 6: 27-34.

Savchyn, Mykhailo. 2009. Constitutionalism and the nature of the Constitution. Uzhhorod: Lira.

Selivanov, Volodymyr. 2001. "Private legal principles of development of domestic legal science". Law of Ukraine 3: 21-32.

Sheindlin, Boris. 1959. The essence of Soviet law. Leningrad: Publishing House of Leningrad State University.

Simon, Valter. 1979. Omnipotence of the unions of entrepreneurs. Alliances in the economic and political system of the FRG. Moscow: Progress.

Solodovnichenko, Tatiana. 2015. "Criteria for differentiating the right to private and public". Omsk University Bulletin 2(43): 42-46.

Spasibo-Fateeva, Inna. 2011. Kharkiv civil school: in the spirit of traditions. Kharkiv: Pravo.

Stefanchuk, Maryna. 2016. The activity of the prosecutor's office to represent the interests of a citizen or the state in court: problems of theory and practice. Kyiv: In Jure.

Stepanenko, Tetiana. 2008. Judicial proceedings in cases of claims for protection of the rights and interests of an indefinite number of persons. Kharkiv: Kharkiv National University of Internal Affairs.

Sybiliov, Mykhailo. 1998. The role of the Constitution of Ukraine in the formation of the system of law and codification of legislation. In: Theoretical and Practical Issues of Implementation of the Constitution of Ukraine: Problems, Experience, Prospects ( $p p$ 154-156). Kharkiv: Pravo.

Talapina, Elvira and Yuriy Tihomirov. 2002. "Public functions in the economy". Law and Economics 6: 3-9.

Tikhomirov, Yuriy. 1995. Public law. Moscow: Norma.

Tikhomirov, Yuriy. 2001. "Public law regulation: dynamics of spheres and methods". Journal of Russian Law 5: 3-12.

Totev, Konstantin. 2002. "Public interest in legal doctrine and legislation". State and Law 9: 16-17.

Tumanov, Dmitriy. 2012. "Problems of public interest protection in the Russian civil process". Russian Laws: Experience, Analysis, Practice 9: 3-11.

Uksusova, Elena. 1997. "Cases on the protection of the rights of an indefinite circle of persons". Russian Justice 11: 42-44.

Vasilyeva, Maria. 2003. Public interests in environmental law. Moscow: MSU.

Venediktova, Iryna. 2014. Protection of legally protected interests in civil law. Kyiv: Yurinkom Inter.

Vinnyk, Oksana, 2004. Theoretical aspects of legal support of realisation of public and private interests in economic societies. Kharkiv: Kharkiv National University of Internal Affairs.

Vinnyk, Oksana. 2001. "Private and public interests, their role and reflection in economic law". Entrepreneurship, Economy and Law 5: 11-13.

Yatsenko, Tatiana. 2016. Civil-legal protection of public interests. Moscow: Lomonosov Moscow State University.

Zabluk, Nikolai. 2002. "Public interest in the context of American pluralistic democracy". USA and Canada: Economy, Politics, Culture 12: 7-10.

\section{DOI: https://doi.org/10.6000/1929-4409.2021.10.51}

\section{(C) 2021 Berestova et al.; Licensee Lifescience Global.}

This is an open access article licensed under the terms of the Creative Commons Attribution Non-Commercial License (http://creativecommons.org/licenses/by-nc/3.0/) which permits unrestricted, non-commercial use, distribution and reproduction in any medium, provided the work is properly cited. 